\title{
An analysis of temporal and generational trends in the incidence of anal and other HPV-related cancers in Southeast England
}

\author{
D Robinson*,', V Coupland' and H Møller' \\ 'Thames Cancer Registry, Division of Cancer Studies, King's College London, Ist Floor, Capital House, Weston Street, London SEI 3QD, UK
}

\begin{abstract}
Patients diagnosed in 1960-2004 with cancer of the cervix, anus, vulva, vagina or penis were identified from the Thames Cancer Registry database, and age-standardised period (temporal) incidence rates calculated by direct standardisation. Age-cohort modelling techniques were used to estimate age-specific incidence rates in the earlier and later cohorts, enabling the calculation of agestandardised cohort (generational) rates. Incidence of anal cancer increased for both men and women over the period studied, mainly in those born from 1940 onwards. Similar generational patterns were seen for cancers of the vulva and vagina, but those for penile cancer were different. For cervix cancer, the steep downward trend in cohort rates due to screening levelled off in women born from 1940 onwards. Our findings are compatible with the hypothesis that changes in sexual practices were a major contributor to the increases of these cancers. Programmes of vaccination against HPV, aimed at reducing the burden of cervical cancer, may also help to reduce the incidence of cancer at other anogenital sites.

British Journal of Cancer (2009) I 00, 527-53I. doi:I0.I038/sj.bjc.660487I www.bjcancer.com
\end{abstract}

Published online 20 January 2009

(c) 2009 Cancer Research UK

Keywords: human papillomavirus; anogenital cancers; cohort effects

Human papillomavirus (HPV), a sexually transmitted pathogen infecting the anogenital epithelium, is the major cause of cervix cancer. In cervical cancer, HPV infection is the major cause (Schiffman et al, 1993; International Agency for Research on Cancer, 1995; zur Hausen, 1996; Walboomers et al, 1999; Schlecht et al, 2001; Bosch et al, 2002; Schiffman et al, 2007; Bosch and de Sanjosé, 2003), and positive associations have been found between HPV infection and cancers of the anus (Daling and Sherman, 1992; Frisch et al, 1997; Daling et al, 2004; Bjørge et al, 2002), vulva and vagina (Madeleine et al, 1997; Daling et al, 2002; Goffin et al, 2006; Madsen et al, 2008). Cancers of the anus, vulva and vagina occur more frequently than expected following cervical intraepithelial neoplasia III or invasive cervical cancer, suggesting a strong common aetiological factor (Evans et al, 2003). HPV infection may also play a role in a subset of penile squamous cell carcinomas (Iwasawa et al, 1993; Rubin et al, 2001; Daling et al, 2005; Heideman et al, 2007; Tornesello et al, 2008).

Increasing trends in anal cancer have been reported, possibly due to changes in sexual practices (Daling et al, 1987; Scholefield et al, 1990; Frisch et al, 1993, 1997). If this were the case, a strong generational effect would be expected in the incidence trends of anogenital cancers. We have explored this hypothesis by plotting age-standardised period (temporal) and cohort (generational) rates for cancer sites linked to HPV infection.

\section{METHODS}

Patients diagnosed in 1960-2004 with cancer of the anus (ICD-10 code C21), vulva (C51), vagina (C52), cervix uteri (C53) or penis

*Correspondence: D Robinson; E-mail: dave.robinson@kcl.ac.uk Received 7 October 2008; revised 5 December 2008; accepted 8 December 2008; published online 20 January 2009
(C60) were identified from the Thames Cancer Registry (TCR) database. TCR is a population-based registry, which in this period covered a population of approximately 12 million residents of London and southeast England. All tumours are coded according to the ICD-O classification (World Health Organization, 1976), and were retrospectively recoded to the ICD-10 classification in the case of tumours diagnosed before its introduction in the early 1990s. Examination of proportional frequency plots revealed no coding discrepancies or inconsistencies over the period of the study. Age at diagnosis was categorised into 5-year groups (0-4, $5-9, \ldots, 80-84,85+)$, and period of diagnosis into 5 -year periods (1960-1964, 1965-1969, .., 2000-2004). Nominal birth cohort groups $(1875,1880, \ldots, 2000)$ were then calculated by subtracting the midpoint of the age group from the midpoint of the period. For each site, an age-standardised incidence rate for each calendar period was calculated by direct standardisation, using the European standard population. As the earlier and later birth cohorts were missing data from the younger and older age groups, respectively, a Poisson regression age-cohort modelling technique (Clayton and Schifflers, 1987) was used to estimate the unavailable rates, enabling the estimation of an age-standardised incidence rate for each cohort. As estimates for later cohorts (represented by younger patients diagnosed in recent periods) were based on small numbers of cases, and hence relatively unreliable, we report only estimates for birth cohorts between 1885 and 1960 .

\section{RESULTS}

Table 1 shows the total number of cancers diagnosed over the study period and the incidence by age for each site. Incidence increases with age at all sites, with few cases (other than cervical cancer cases) occurring before age 55 . 
Figure 1A shows a modest increase in age-standardised period rates for anal cancer in both men and women. In men, these increased from 0.79 in 1960-64 to 1.06 per 100000 in 2000-2004. In women, the increase was greater, from 0.45 in 1960-64 to 1.18 per 100000 in 2000-2004. In both sexes, rates for consecutive cohorts (Figure 1B) remained relatively constant (between 0.5 and 1.1 per 100000 ) for individuals born between 1885 and 1935. There was then a sharp increase in rates in the subsequent generations born from 1940 onwards. In men, the rates increased from 0.92 in the 1935 cohort to 1.71 per 100000 in the 1960 cohort, whereas in women the increase was from 0.97 in the 1935 cohort to 4.18 per 100000 in the 1960 cohort.

Figure 2A and B show age-standardised rates, by period and cohort, respectively, for cancers of the vulva and vagina. Period rates have remained fairly constant since the early 1990s, whereas cohort rates have increased in recent generations: for vaginal cancer, from 0.42 in the 1940 cohort to 0.82 per 100000 in the 1960 cohort; the corresponding rise for vulval cancer was from 1.65 to 2.51. For penile cancer, period rates have remained fairly constant, whereas cohort rates have been erratic, with no clear pattern emerging (Figure $3 \mathrm{~A}$ and $\mathrm{B}$ ).

Figure 4A and $\mathrm{B}$ show age-standardised period and cohort rates for cervical cancer. Period rates have shown a dramatic decline from 12.68 in those diagnosed between 1985 and 1990 to 6.66 per 100000 in 2000-04. Cohort rates declined from 21.27 in the 1885 cohort to 7.64 per 100000 in the 1935 cohort, after which they remained relatively constant. Table 2 summarises these results, showing the age-standardised rates and associated $95 \%$ confidence levels.

\section{DISCUSSION}

Anal cancer incidence in southeast England increased in both men and women over the study period (1960-2004), by threefold in women and about 1.5-fold in men; the incidence is now higher in women than in men. Similar trends have been seen in Denmark (Frisch et al, 1993), the United States of America (Melbye et al, 1994; Johnson et al, 2004) and Sweden (Goldman et al, 1989). Increases have also been reported in Scotland (Brewster and Bhatti, 2006), where the change in male rates has roughly paralleled that in the female rates from the mid-1970s to the mid-1990s. Male rates have since plateaued, whereas female rates have continued to rise. In Scotland the female rates were higher than the males rates throughout the period studied, whereas in our population these were initially lower than in men, but became higher from the early 1990 s onwards.

Judson et al (2006) found a $20 \%$ increase in invasive vulval cancer in the United States of America between 1973 and 2000. No increase was seen in the period rates for vulval cancer in our data, nor any increase in the period rates for cancers of the vagina or penis.

The dramatic decline in rates for cervical cancer from the late 1980 s onward is similar to that reported in the West Midlands (Clare et al, 2008), and reflects the introduction of the National Health Service's screening programme around 1988, which has led to the early detection of precancerous cervical lesions and the prevention of many invasive cancers.

In our study, in both sexes a marked increase was found in the cohort rates for anal cancer in those born from around 1940 onwards. Similar generational patterns were seen for cancers of the vulva and vagina, consistent with a common aetiology. The most likely causes are changes in sexual practice and greater exposure to infectious agents such as HPV. For cancer of the cervix, for which HPV is generally recognised as the major cause, the steep downward trend in cohort rates due to screening levelled off in women born from 1940 onwards.

We found no clear-cut change in cohort rates for penile cancer, although on average the rates for generations born after 1940 were

Table I Cancer incidence rates per 100000 by age at diagnosis

\begin{tabular}{|c|c|c|c|c|c|c|c|c|}
\hline \multirow[b]{2}{*}{ Cancer site } & \multicolumn{7}{|c|}{ Age } & \multirow[b]{2}{*}{ Total cancers diagnosed } \\
\hline & $<35$ & $35-44$ & $45-54$ & $55-64$ & $65-74$ & $75-84$ & $85+$ & \\
\hline Anus, males & 0.02 & 0.39 & 0.97 & 2.14 & 3.41 & 5.45 & 7.28 & 1988 \\
\hline Anus, females & 0.03 & 0.44 & 1.18 & 1.95 & 3.37 & 4.75 & 6.60 & 2676 \\
\hline Vulva & 0.09 & 0.74 & 1.46 & 3.15 & 7.44 & 14.24 & 22.86 & 6216 \\
\hline Vagina & 0.04 & 0.24 & 0.66 & 1.06 & 1.80 & 3.46 & 4.19 & 1639 \\
\hline Penis & 0.04 & 0.46 & 0.94 & 1.92 & 3.49 & 6.08 & 10.24 & 2082 \\
\hline Cervix & 2.93 & 16.21 & 18.34 & 19.89 & 20.25 & 20.34 & 19.43 & 25854 \\
\hline
\end{tabular}

A

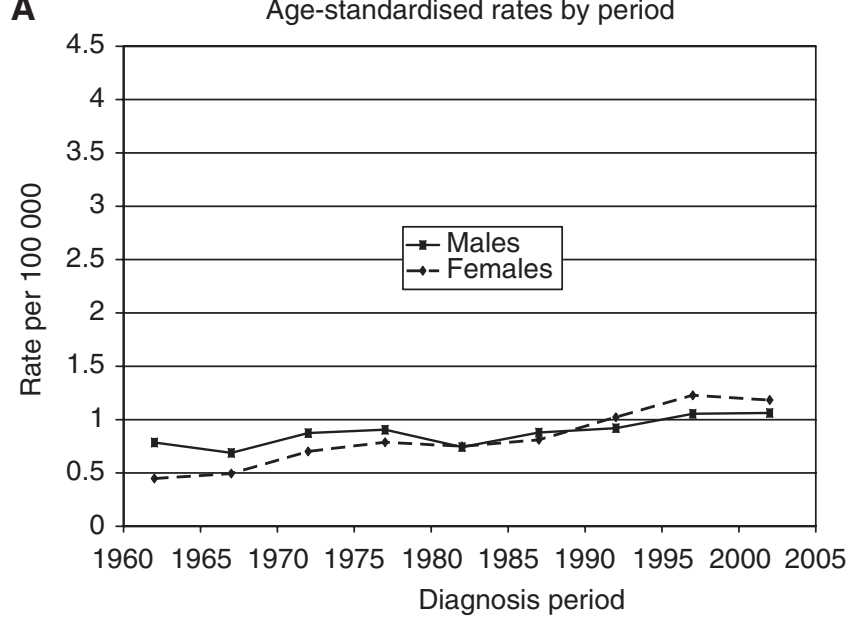

B

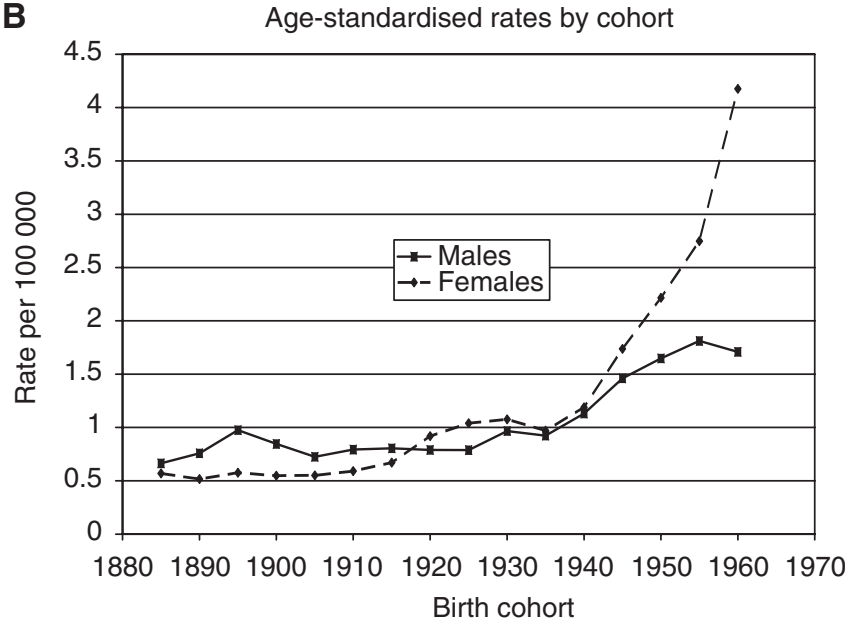

Figure I Anal cancer. (A) Age-standardised rates by period. (B) Age-standardised rates by cohort. 
A

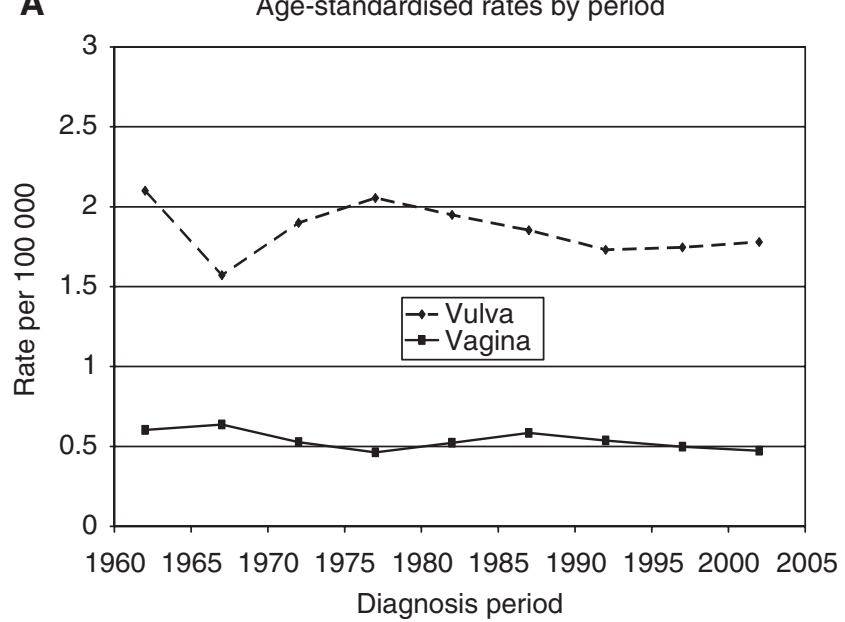

B

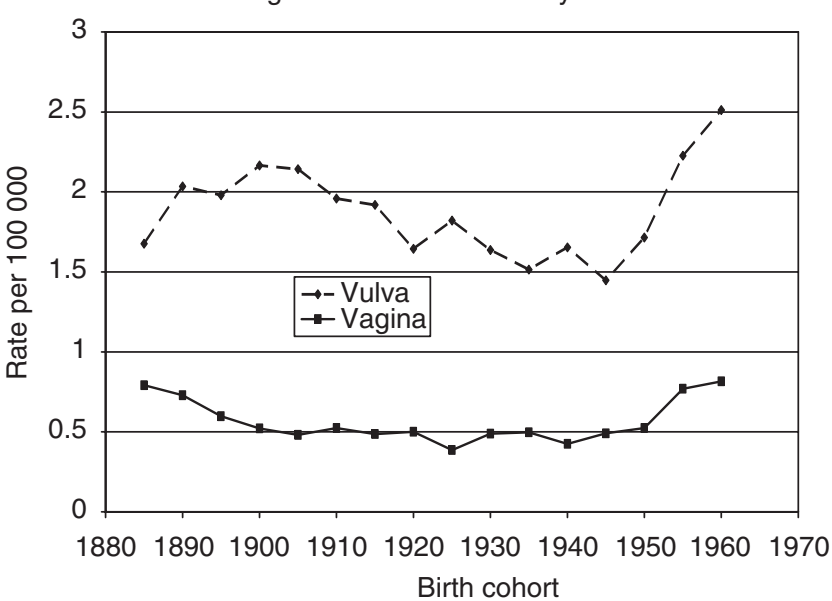

Figure 2 Vulval and vaginal cancers. (A) Age-standardised rates by period.

B) Age-standardised rates by cohort.

A

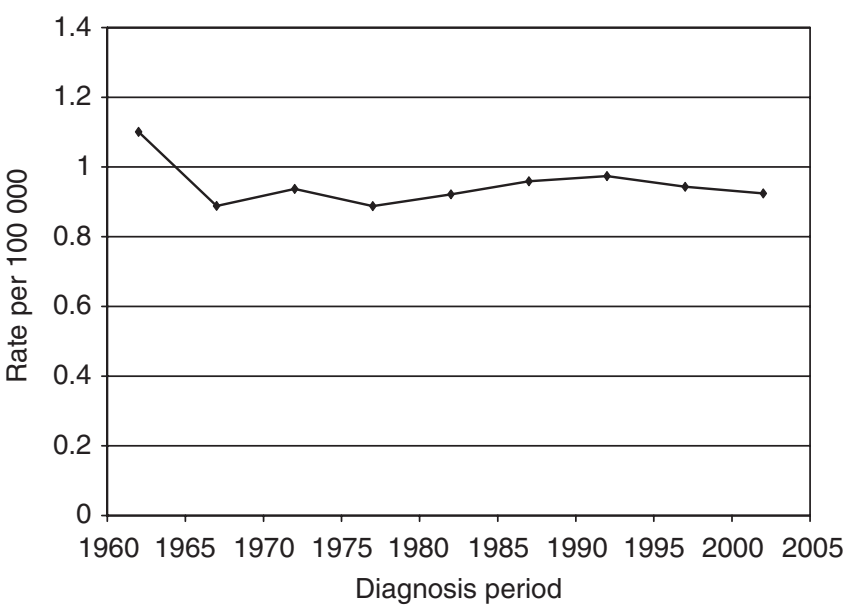

B

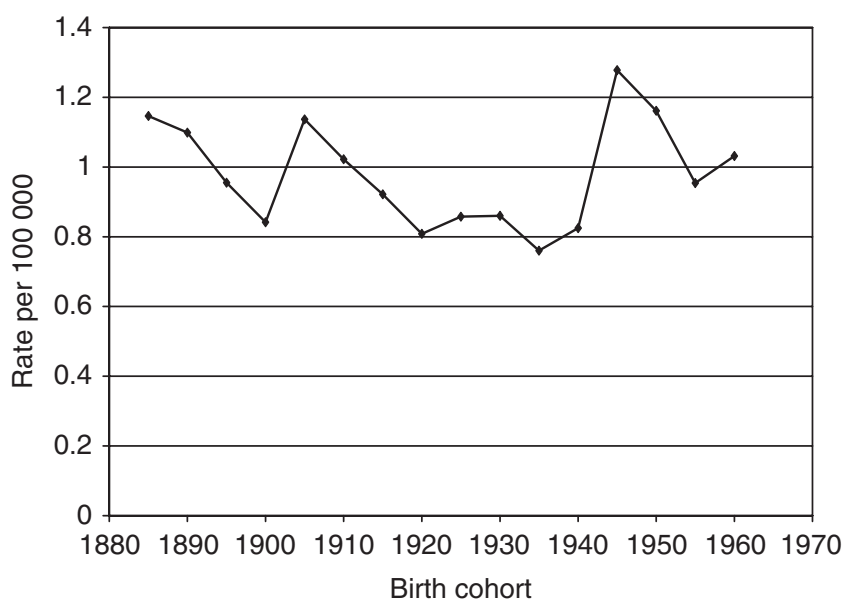

Figure 3 Penile cancer. (A) Age-standardised rates by period. (B) Age-standardised rates by cohort.

higher than in previous cohorts. It may be that the effect of HPV infection is less in penis cancer than in the other cancers, as recently suggested (Tornesello et al, 2008).

Several studies have linked sexual behaviour with cancer of the anus (Daling et al, 1987; Scholefield et al, 1990; Frisch et al, 1993, 1997). In both Denmark (Melbye and Biggar, 1992) and Scotland (Brewster and Bhatti, 2006) a higher prevalence of receptive anal intercourse in women than in men has been reported, and may explain in part the higher incidence of anal cancer in women in these countries. Sexual practices have also been implicated in cancers of the vagina and vulva (Sherman et al, 1991; Madsen et al, 2008) and of the penis (Maden et al, 1993).

It should be noted that the cohorts which show the recent increases in incidence are, of necessity, based partially on modelled data, because observational data in the older age groups are not available. However, the variability introduced by the modelling procedure has been included in the calculation of the standard errors of the estimated rates. As can be seen from Table 2, none of the estimates exhibits excessive variation.
The generational patterns seen in the cohort rates presented in this paper, with a marked change from around 1940, while not constituting proof, are compatible with the hypothesis that changes in sexual practices are a major contributor to the increases in anogenital cancers other than the cervix. Those born around 1940 would have been in their early twenties at the start of the 'sexual revolution' in the early 1960s.

Peto et al (2004) have estimated that 'cervical cancer screening has prevented an epidemic that would have killed about one in 65 of all British women born since 1950 and culminated in 6000 deaths per year in this country'. Trials of vaccination against HPV in teenage girls are currently underway in the United Kingdom. In Australia, it has been predicted that the public vaccination programme begun in 2007 will result in a reduction in the agestandardised incidence of HPV-16 infections of $56 \%$ by 2010 and $92 \%$ by 2050 (Smith et al, 2008). Programmes of vaccination, aimed at reducing the burden of cervical cancer, may also help to reduce the incidence of cancers of the vulva, vagina and anus in women. 

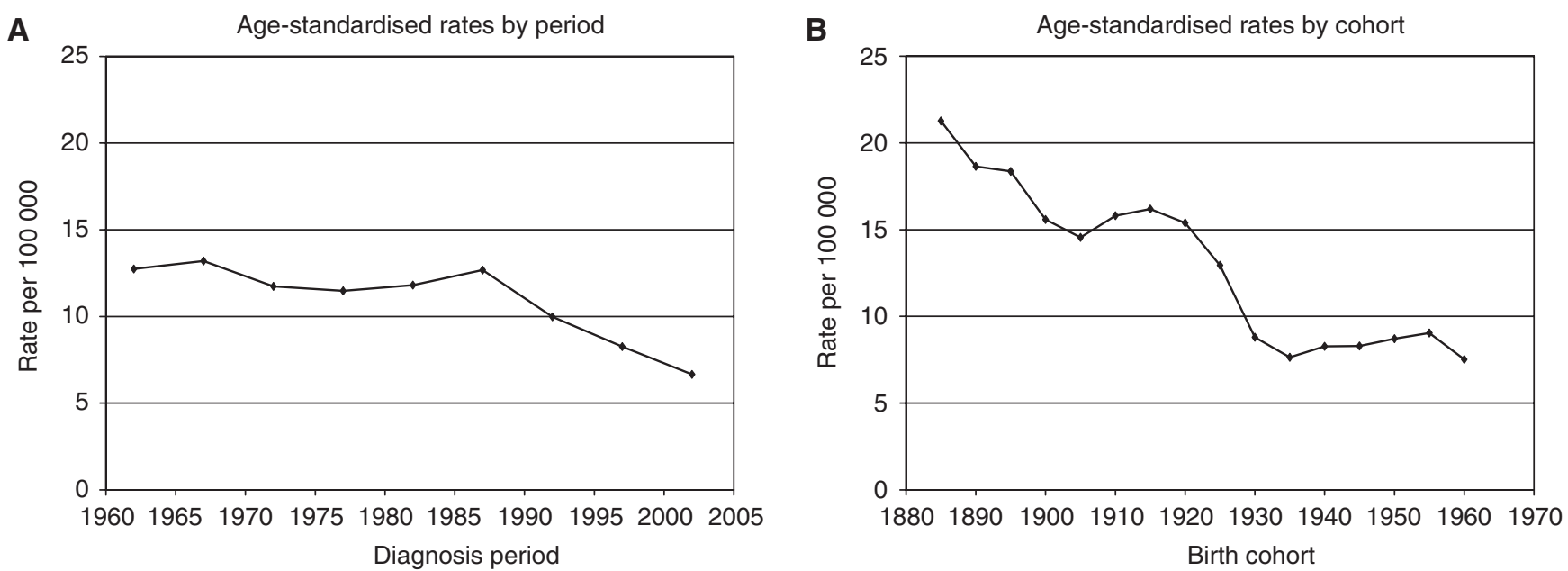

Figure 4 Cervical cancer. (A) Age-standardised rates by period. (B) Age-standardised rates by cohort.

Table 2 Age-standardised incidence rates (per 100,000) and 95\% confidence intervals

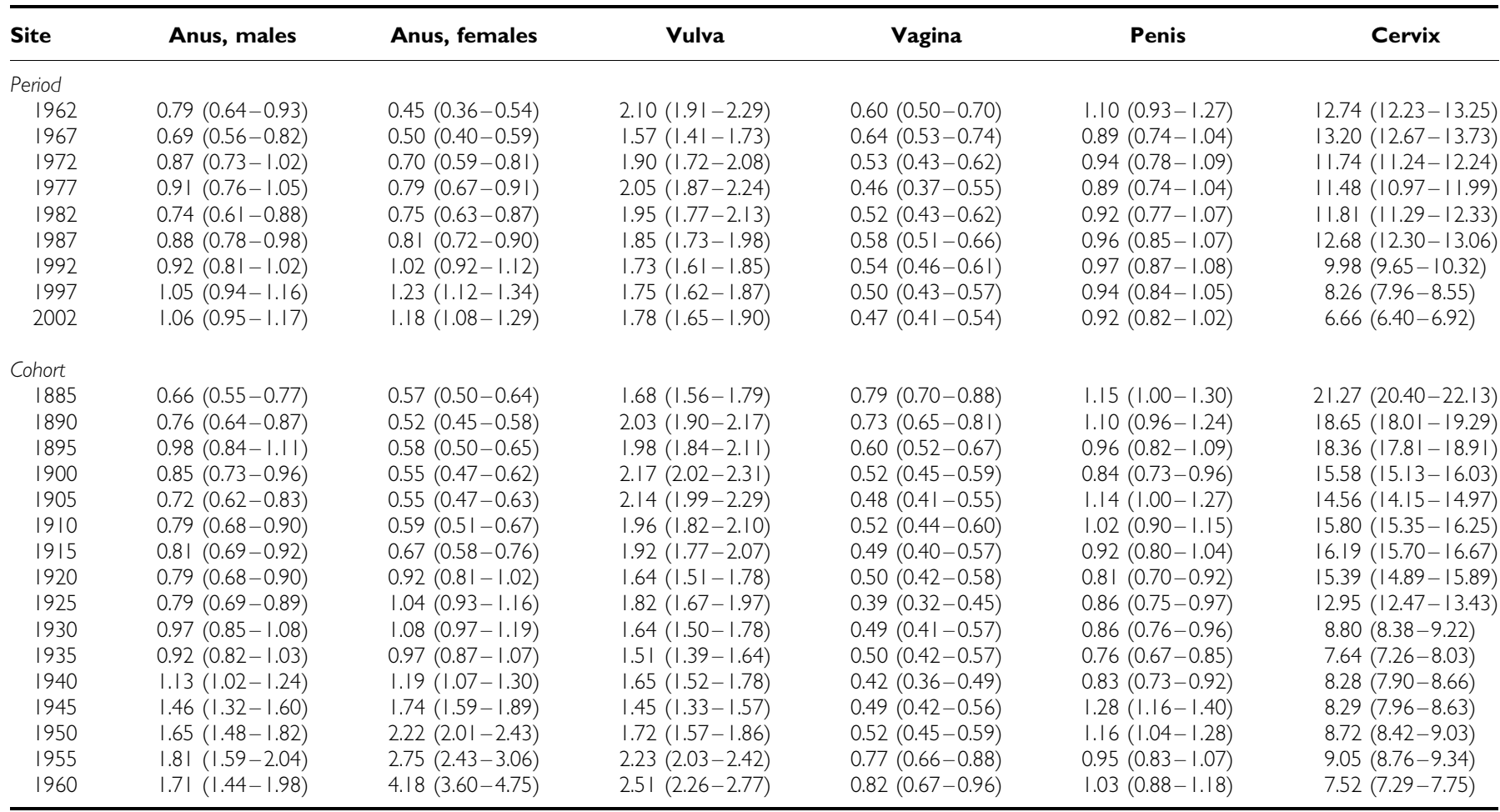

\section{REFERENCES}

Bjørge T, Engeland A, Luostarinen T, Mork J, Gislefoss RE, Jellum E, Koskela P, Lehtinen M, Pukkala E, Thoresen SØ, Dillner J (2002) Human papillomavirus infection as a risk factor for anal and perianal skin cancer in a prospective study. Br J Cancer 87: 61-64

Bosch FX, de Sanjosé S (2003) Chapter 1: Human papillomavirus and cervical cancer - burden and assessment of causality. J Natl Cancer Inst Monogr 31: 3-13

Bosch FX, Lorincz A, Muñoz N, Meijer CJ, Shah KV (2002) The causal relation between human papillomavirus and cervical cancer. J Clin Pathol 55: 244-265

Brewster D, Bhatti LA (2006) Increasing incidence of squamous cell carcinoma of the anus in Scotland, 1975-2002. Br J Cancer 95: 87-90

Clare J, Edwards D, Bagnall H, Pearmain P, Lawrence G (2008) The use of cervical screening history data to interpret cervical cancer incidence trends. J Public Health 30: 171-177

Clayton D, Schifflers E (1987) Models for temporal variation in cancer rates. I: Age-period and age-cohort models. Stat Med 6: 449-467

Daling JR, Madeleine MM, Johnson LG, Schwarz SM, Shera KA, Wurscher MA, Carter JJ, Porter PL, Galloway DA, McDougall JK (2004) Human papillomavirus, smoking and sexual practices in the etiology of anal cancer. Cancer 101: 270-280

Daling JR, Madeleine MM, Johnson LG, Schwartz SM, Shera KA, Wurscher MA, Carter JJ, Porter PL, Galloway DA, McDougall JK, Krieger JN (2005) Penile cancer: Importance of circumcision, human papillomavirus and smoking in in situ and invasive disease. Int J Cancer 116: 606-616

Daling JR, Madeleine MM, Schwartz SM, Shera KA, Carter JJ, McKnight B, Porter PL, Galloway DA, McDougall JK, Tamimi H (2002) A populationbased study of squamous cell vaginal cancer; HPV and cofactors. Gynecol Oncol 84: 263-270 
Daling JR, Sherman KJ (1992) Relationship between human papillomavirus infection and tumours of anogenital sites other than the cervix. In The epidemiology of cervical cancer and human papillomaviruses (IARC scientific publication No 119) Muñoz N, Bosch FX, Shah KV, Meheus A (eds), pp 223-241. Lyon: International Agency for Research on Cancer

Daling JR, Weiss NS, Hislop TG, Maden C, Coates RJ, Sherman KJ, Ashley RL, Beagrie M, Ryan JA, Corey L (1987) Sexual practices, sexually transmitted diseases, and the incidence of anal cancer. N Engl J Med 317: 973- 977

Evans HS, Newnham A, Hodgson SV, Møller H (2003) Second primary cancers after cervical intraepithelial neoplasia III and invasive cervical cancer in Southeast England. Gynecol Oncol 90: 131-136

Frisch M, Glimelius B, van den Brule AJC, Wohlfahrt J, Meijer CJLM, Walboomers JMM, Goldman S, Svensson C, Adami H-O, Melbye M (1997) Sexually transmitted infection as a cause of anal cancer. $N$ Engl J Med 337: $1350-1358$

Frisch M, Melbye M, Møller H (1993) Trends in incidence of anal cancer in Denmark. Br Med J 306: 419-422

Goffin F, Mayrand M-H, Gauthier P, Alobaid A, Lussier C, Provencher D, Drouin P, Franco EL, Coutlée F (2006) High-risk human papillomavirus infection of the genital tract of women with a previous history or current high-grade vulvar intraepithelial neoplasia. J Med Virol 78: 814-819

Goldman S, Glimelius B, Nilsson B, Påhlman L (1989) Incidence of anal epidermoid carcinoma in Sweden 1970-1984. Acta Chir Scand 155: 191 - 197

Heideman DAM, Waterboer T, Pawlita M, Delis-van Diemen P, Nindl I, Leijte JA, Bonfrer JMG, Horenblas S, Meijer CJLM, Snijders PJF (2007) Human papillomavirus-16 is the predominant type etiologically involved in penile squamous cell carcinoma. J Clin Oncol 25: 4550-4556

International Agency for Research on Cancer (1995) IARC monographs on the evaluation of carcinogenic risks to humans, Vol. 64. Human papillomaviruses. Lyon: International Agency for Research on Cancer

Iwasawa A, Kumamoto Y, Fujinaga K (1993) Detection of human papillomavirus deoxyribonucleic acid in penile carcinoma by polymerase chain reaction and in situ hybridization. J Urol 149: 59-63

Johnson LG, Madeleine MM, Newcomer LM, Schwartz SM, Daling JR (2004) Anal cancer incidence and survival: the surveillance, epidemiology, and end results experience, 1973-2000. Cancer 101: 281-288

Judson PL, Habermann EB, Baxter NN, Durham SB, Virnig BA (2006) Trends in the incidence of invasive and in situ vulvar carcinoma. Obstet Gynecol 107: 1018-1022

Madeleine MM, Daling JR, Carter JJ, Wipf GC, Schwartz SM, McKnight B, Kurman RJ, Beckmann AM, Hagensee ME, Galloway DA (1997) Cofactors with human papillomavirus in a population-based study of vulvar cancer. I Natl Cancer Inst 89: 1516-1523

Maden C, Sherman KJ, Beckmann AM, Hislop TG, Te C-Z, Ashley RL, Daling JR (1993) History of circumcision, medical conditions, and sexual activity and risk of penile cancer. J Natl Cancer Inst 85: 19-24
Madsen BS, Jensen HL, van den Brule JC, Wohlfahrt J, Frisch M (2008) Risk factors for invasive squamous cell carcinoma of the vulva and vagina population-based case-control study in Denmark. Int J Cancer 122: $2827-2834$

Melbye M, Biggar RJ (1992) Interactions between persons at risk for AIDS and the general population in Denmark. Am J Epidemiol 135: 593-602

Melbye M, Rabkin C, Frisch M, Biggar RJ (1994) Changing patterns of anal cancer incidence in the United States, 1940-1989. Am J Epidemiol 139: $772-780$

Peto J, Gilham C, Fletcher O, Matthews FE (2004) The cervical cancer epidemic that screening has prevented in the UK. Lancet 364: 249-256

Rubin MA, Kleter B, Zhou M, Ayala G, Cubilla AL, Quint WG, Pirog EC (2001) Detection and typing of human papillomavirus DNA in penile carcinoma: evidence for multiple independent pathways of penile carcinogenesis. Am J Pathol 159: 1211-1218

Schiffman MH, Bauer HM, Hoover RN, Glass AG, Cadell DM, Rush BB, Scott DR, Sherman ME, Kurman RJ, Wacholder S, Stanton CK, Manos MM (1993) Epidemiologic evidence showing that human papillomavirus infection causes most cervical intraepithelial neoplasia. J Natl Cancer Inst 85: $958-964$

Schiffman M, Castle PE, Jeronimo J, Rodriguez AC, Wacholder S (2007) Human papillomavirus and cervical cancer. Lancet 370: $890-907$

Schlecht NF, Kulaga S, Robitaille J, Ferreira S, Santos M, Miyamura RA, Duarte-Franco E, Rohan TE, Ferenczy A, Villa LL, Franco EL (2001) Persistent human papillomavirus infection as a predictor of cervical intraepithelial neoplasia. JAMA 286: 3106-3114

Scholefield JH, Thornton Jones H, Cuzick J, Northover JMA (1990) Anal cancer and marital status. Br J Cancer 62: 286-288

Sherman KJ, Daling JR, Chu J, Weiss NS, Ashley RL, Corey L (1991) Genital warts, other sexually transmitted diseases, and vulvar cancer. Epidemiology 2: $257-262$

Smith MA, Canfell K, Brotherton JML, Lew J-B, Barnabas RV (2008) The predicted impact of vaccination on human papillomavirus infections in Australia. Int J Cancer 123: 1854-1863

Tornesello ML, Duraturo ML, Losito S, Botti G, Pilotti S, Stefanon B, De Palo G, Gallo A, Buonaguro L, Buonaguro FM (2008) Human papillomavirus genotypes and HPV16 variants in penile carcinoma. Int J Cancer 122: $132-137$

Walboomers JM, Jacobs MV, Manos MM, Bosch FX, Kummer JA, Shah KV, Snijders PJ, Peto J, Meijer CJ, Muñoz N (1999) Human papillomavirus is a necessary cause of invasive cervical cancer worldwide. J Pathol 189: $12-19$

World Health Organization (1976) International Classification of Diseases for Oncology. Geneva: World Health Organization

zur Hausen H (1996) Papilloma virus infections - a major cause of human cancers. Biochim Biophys Acta 1288: F55-F78 